\title{
Study of animal welfare through analysis and comparison of the presence of foot pad dermatitis in broilers raised in controlled environments in Brazil and Spain ${ }^{1}$
}

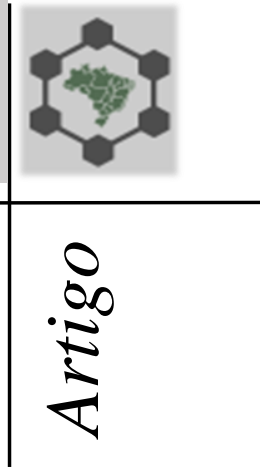

Estudo do bem estar animal mediante analise e comparação da presença de pododermatite em frangos de corte criados em ambientes controlados no Brasil e Espanhal

\section{Walbens Siqueira Benevides*², Manuel Pizarro-Díaz ${ }^{3}$, Luiz Eduardo Guano ${ }^{3}$, Ana Raquel de Almeida ${ }^{2}$, Levi de Oliveira Frota ${ }^{2}$, Wanessa de Oliveira Campos ${ }^{2}$, Plácido Washington Cabral Pinto $^{4}$}

\author{
${ }^{1}$ Artigo científico obtido do estágio pós-doutoral do primeiro autor. \\ ${ }^{2}$ Group Studies in Poultry Industry, Faculty of Veterinary, State University of Ceara (UECE), \\ Brazil; E.Mail: walbens.benevides@uece.br, kel_almeida92@hotmail.com, levimv@ hotmail.com, \\ wanexinhacampos@gmail.com \\ ${ }^{3}$ Department of Medicine and Surgery, Faculty of Veterinary of Complutense University of Madrid \\ (UCM), Spain. E.Mail: mpizarro@vet.ucm.es, eduguano@hotmail.com \\ ${ }^{4}$ Technical department of the company Pacatuba Hortigranjeira. E.Mail: placidozootecnia@gmail.com
}

\begin{abstract}
The pododermatitis interacts directly with the animal welfare, it is a disease that alters the behavior, causing serious discomfort to the animals and is also a port for incoming pathogens, being the legs constantly on the chickens litter. We collected data of male and female chicken's feet with 14, 28 and 42 days of age, in four negative pressures poultry (A, B, C and D) with controlled temperature, either of the coolers side and of the exhausters side, totaling 144 birds in hot season in Brazil and 144 birds in cold season in Spain, applying an evaluation of injury scores of 1-4. Males and females showed no significant differences in any country, although the media in Brazil were higher. In Spain the aviary A showed higher scores of injuries and in Brazil there was no significant difference in any aviary. Regarding ages, in animals with 28 and 42 days, the lesions were significantly bigger than 14 days in both countries. The scores on hand showed significant differences only for the media in Brazil, which were higher than that of Spain. Being the area of the coolers more wet, this indicates that it may increase the injury index, with the aggravation of the external temperature and relative humidity of the air higher in Brazil. We conclude that the external ambience influences the internal ambience and added to the management and reuse of the litter may interfere in increasing injury score as the birds gain more weight.
\end{abstract}

Keywords: cushion plant lesion, contact dermatitis, negative pressure, ambience.

Resumo: A pododermatite interage diretamente com o bem estar animal, pois é uma enfermidade que altera o comportamento, provocando serio desconforto aos animais, sendo também uma porta para entrada de patógenos, por estarem às patas constantemente sobre a cama das aves. Coletamos dados de patas de frangos machos e fêmeas com 14, 28 e 42 dias de idade, em quatro aviários (A, B, C e D) climatizados de pressão negativa tanto do lado dos resfriadores como do lado dos exaustores, no total de 
144 aves em época quente no Brasil e 144 aves em época fria na Espanha, aplicando a avaliação de escores de lesões de 1 a 4. Machos e fêmeas não apresentaram diferenças significativas em nenhum país, embora que as medias do Brasil foram superiores. Na Espanha o aviário A apresentou um maior escore de lesões e no Brasil não houve diferença significativa em nenhum aviário. Quanto às idades, com 28 e 42 dias, as lesões foram maiores significativamente que 14 dias em ambos os países. Os escores por lado apresentaram diferenças significativas somente para as medias do Brasil, que foram superiores que as da Espanha. Por ser a área dos resfriadores mais úmida, indica que pode aumentar o índice de lesões, com o agravante das temperaturas externas e umidade relativa do ar mais elevadas no Brasil. Concluímos que a ambiência externa influencia na ambiência interna e somado ao manejo e reaproveitamento de cama, sugerem interferir no aumento escore de lesões na medida que as aves ganham mais peso.

Palavras chave: lesão do coxim plantar, dermatite de contato, pressão negativa, ambiência.

Autor para correspondência. E. Mail: *walbens.benevides@uece.br

Recebido em 11.7.2016. Aceito em 28.9.2016

http://dx.doi.org/10.5935/1981-2965.20160028

\section{Introduction}

The poultry industry has been able

(GOCSIK et al., 2016). Industrial chickens to develop high-level technologies in these more than one hundred years of existence, reaching high zootechnical results. These advances have been obtained through a lot of financial investment in ambience, making the handling work more efficient. However, to offset this economic contribution, the producers were taken to increase the population density in aviary, mainly broiler chickens, currently one of the most discussed and questionable points regarding the BEA (Animal Welfare).

BEA has been a major problem in Europe over the past decades (Saraiva et al., 2016) and evolved throughout the world, yet the increase in BEA requirements, generally results in an increase in production costs type broiler, as well as the commercial laying hens to produce more and quickly, are genetically improved and submitted to an intensive confinement system with automated comfortable ambience, coupled with high density and nutritional diets high density, along with a sophisticated biosecurity to prevent diseases (BENEVIDES et al., 2013a, 2013b).

As a scientific interpretation for $\mathrm{BEA}$, the representation most accepted is based on the five liberties, which are: (1) free of hunger and thirst; (2) freedom from discomfort; (3) free from pain, injury and disease; (4) free to express their typical behavior; and (5) free from fear and anguish (FAROUK et al., 2016). 
In the category of productivity, Brazil occupies a great prominence place in the global poultry industry, because, as the third largest producer in constantly growing and largest exporter of poultry meat (ABPA, 2016), must always be excelling in their results. Parallel to the zootechnical progress, the demands of society such as food safety, traceability, environmental protection and sustainability, has also evolved, among these, we highlight the BEA as the focus of our work. In conventional production systems it is necessary to provide permanent access to food and water at a maximum density of $42 \mathrm{~kg} / \mathrm{m} 2$, if the creations have adequate ventilation and heating (FAROUK et al., 2016). Furthermore, the high density in the production of broilers affects BEA, because it provides weakness in the legs, the shank and foot pads (Zhang et al., 2011), and also the increase in air temperature can cause serious problems related to thermal comfort.

The commercialization of chicken feet, in Brazil, is directed to Asian markets (ABPA, 2016), this factor adds value to a low acceptance product on the intern market, favoring the profitability of Brazilian companies, however, pododermatite is a critical problem which can compromise exports of chickens (Teixeira et al., 2015), because they are eatable parts of the bird that are in high demand, especially in Southeast Asia (ZHANG et al., 2011). Chicken legs are considered a culinary delicacy in many cultures and became tthird most economically important part of the chicken, after the breast and wings, which are first and second, respectively (CHEN et al., 2016).

The pododermatitis or footpad lesions or contact dermatitis (Berchieri JR. et al., 2009), interacts directly with the BEA, because besides harming productivity and increase the sentences of broiler carcass parts in slaughter houses, is a disease that changes the behavior of birds raised on the floor and causes serious discomfort to the animals.

The lesions in the footpad can become a gateway for bacterial infections (for example Staphylococci), that will affect the health of the bird (Bassler et al., 2013), being the paws continuously on the chickens litter. Furthermore, the plantar cushion dermatitis demonstrated compromise the weight gain in the rate of $7.75 \%$ and feed conversion efficiency in $4.16 \%$, respectively, in 37 days of production (DUNLOP et al., 2016). 
The lesions usually begin with discolouration of the skin, followed by inflammation, erosions and hyperkeratosis of the skin, which can progress to ulceration and necrosis of the epidermis. (WEBER et al., 2015). The pododermatite was classified as an economic problem for the poultry industry of broilers and turkeys in the UK, North America and Australia, due to inadequate conditions of litter, especially the excess of humidity (SANTOS et al., 2002). Lesions that are caused by pododermatite are a concern to the poultry industry as the cause of the BEA is considered very important, especially in Europe (SHEPHERD; FAIRCHILD, 2010).

Besides causing the degradation of the leg quality and economic loss, the appearance of lesions on the legs, is now used as an evaluation criterion of BEA in poultry production systems in Europe and the USA (CHEN et al., 2016). Due to the value of this product on the market also as the growing issues of BEA, are the main interests of the poultry industry to reduce sentences for this cause in industrial abattoirs (SHEPHERD; FAIRCHILD, 2010). Studies conducted in the United Kingdom report an average prevalence of $14.8 \%$ of pododermatitis in 86 batches of 21 conventional chicken farms, and the average prevalence of $98.1 \%$ was found in 128 batches of 23 organic chicken farms (ASK, 2010).

Repeated use of litter is being a common practice in Brazilian aviaries, mainly due to factors such as difficulty and replacement costs as well as this destination at the end of each created broiler batch (MENDES et al., 2004). However, this practice, even with appropriate management, after an excessive period, can cause a hardening of litter and take to more frequent appearance of pododermatite (Berchieri JR. et al., 2009), which worsens as the birds gain weight and it occurs with a higher proportion from 28 days of age.

Factors such as high humidity and consequent increase in ammonia in high population density, especially in the modern environment of computerized aviaries controlled by exhausters, nebulisers and coolers type cooling (Mendes et al., 2004), can be considered as aggravating the occurrence of foot pad dermatitis, when the birds are also on reused litter.

The appearance of lesions in the footpad of the bird begins with an inflammation of the skin that is in permanent contact with the litter, which associated with corrosive factors present in it, speed up a ulcerative process, because as exist a lot of 
faeces on the litter, caused by the high densities in commercial poultry production, the results can be evolutive and progressive.

The pododermatite is an important marker of degradation of poultry litter, due to the high density accommodation that is severely criticized by animal welfare associations (Bernardi, 2011), mainly associated with repetitive use of litter for several creations and even for years, being removed often only partially when it exceeds the low walls of the aviaries.

These modern aviaries are already used around the world, whether in areas of high or low temperatures and with relative humidity varies according to the region, however we do not know if these external environmental factors can change and provide an effect or not the occurrence of foot pad dermatitis.

Pododermatitis is a condition of the broilers legs which is diagnosed by the observation of a dark brown color stained on its feet, at the broiler, the lesion can also be found in the hocks (MARTRENCHAR et al., 2002).

The pododermatitis has been considered as a kind of footpad contact dermatitis in chickens, since it occurs at the points of contact with the ground (HASHIMOTO et al., 2011). The lesions usually begin with discolouration of the skin, followed by inflammation, erosions and hyperkeratosis of the skin, which can progress to ulceration and necrosis of the epidermis (WYNEKEN WEBER et al., 2015).

These foot lesions are associated with various environmental and nutritional factors (Gleice \& Alves, 2013) such as diet, nutritional deficiencies, wet litter, types of sand materials, sex, weight of the birds, the season and density (Wyneken Weber et al ., 2015), noting that Martrenchar et al. (2002) observed that this last item increases the prevalence of pododermatitis in industry broilers.

The cushion plant lesion in broiler chickens, is one criterion of condemnation on health inspection during slaughter, where these economic losses can be a significant loss for the company and integrated, and also for the export market (SINCLAIR et al., 2015).

To evaluate with a single standard of podermatitis injury scores, according to Ask (2010), there are different types of scores for classification in industrial abattoirs inspected. Hashimoto et al., (2011), classified the footpad lesions in 4 types of scores, where 0 was no injury, score 1 for injuries in some areas $(<50 \%)$ of the 
footpad, a score of 2 for lesions large areas (between 50\% and 100\%) of the paw and score 3 to injuries throughout the area the footpad and around. Despite being a subjective analysis by macroscopic observation, as occurs in industrial poultry slaughterhouses, the important thing is not escape of standards already established by some authors. Therefore, there is not yet a single rule for evaluation of scores of

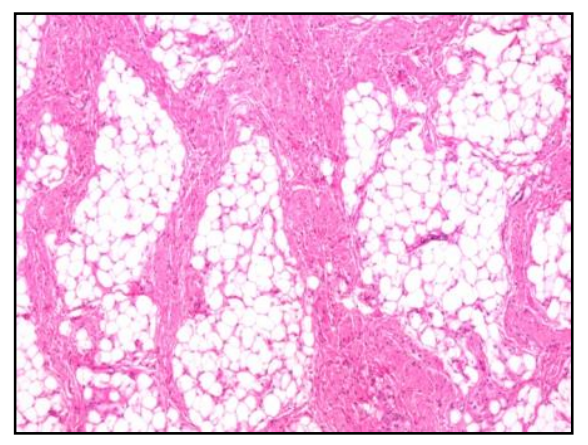

Figure 1: Fibrosis (multiplication x20) injuries to pad dermatitis, however all authors, always consider a lack the presence of severe injuries, gradually and progressively, which can start at zero or 1 , going up to 4 or 5 respectively. In the histological aspect, we see in Figures 1 and 2 a moderate fibrosis in the subcutaneous tissue that we can consider as score 1, with an increase of fibrous tissue around the adipose tissue that composes the footpad.

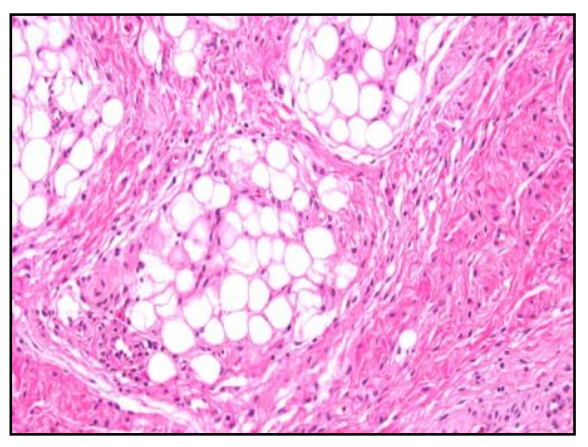

Figure 2: Fibrosis (multiplication x100)

Source: Histology Laboratory, Faculty of Veterinary of Complutense University of Madrid.

In Figures 3 and 4 we observed a hyperkeratosis which features a thickening

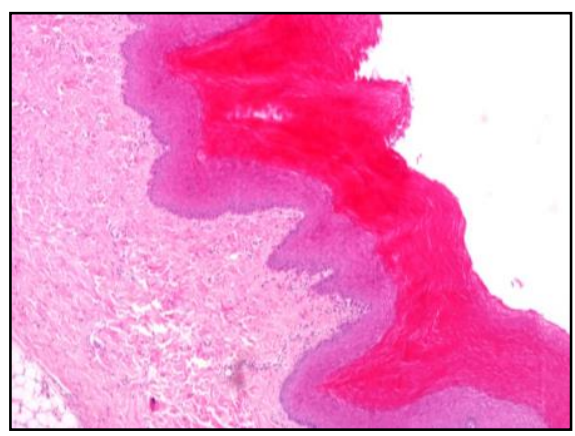

Figure 3: Hyperkeratosis (multiplication x20) or hypertrophy of the stratum corneum of the epithelium, achieving a score of 2.

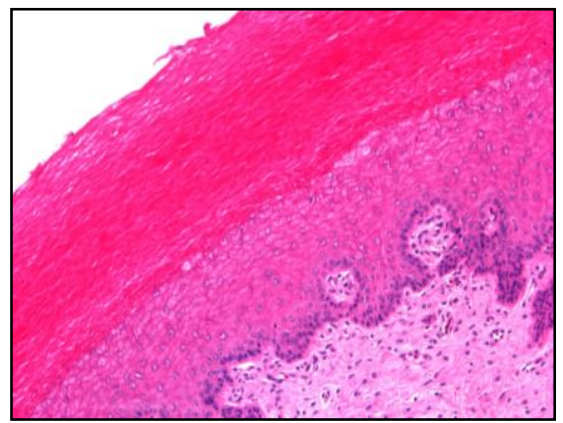

Figure 4: Hyperkeratosis (objective x100)

Source: Histology Laboratory, Faculty of Veterinary of Complutense University of Madrid.

Whereas as a score of 3 (Figures 5 and 6), we find a greater hyperkeratosis and a small ulcer of the epithelial tissue (skin) with loss of focal coating, accompanied by an inflammation of the connective tissue (dermis) with dilated vessels, edema and 
infiltration of polymorphonuclear leukocytes heterophile and some lymphocytes and

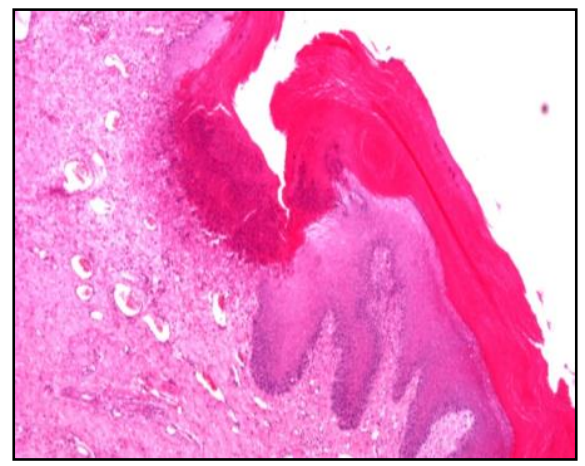

Figure 5: Hyperkeratosis (multiplication x40) histiocytes.

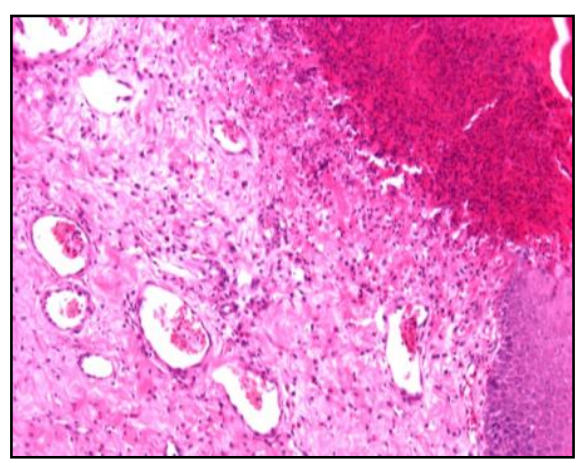

Figure 6: Hyperkeratosis (multiplication x100)

Source: Histology Laboratory, Faculty of Veterinary of Complutense University of Madrid.

In Figures 7 and 8 we see how a of the dermis with extensive fibrosis and score 4, an extensive necrosis of the disorganization of the adipose tissue. epithelial tissue, accompanied by a change

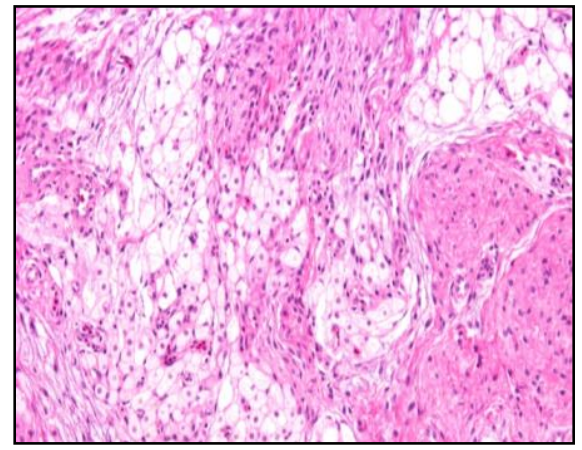

Figure 7: Pododernatitis (multiplication x100)

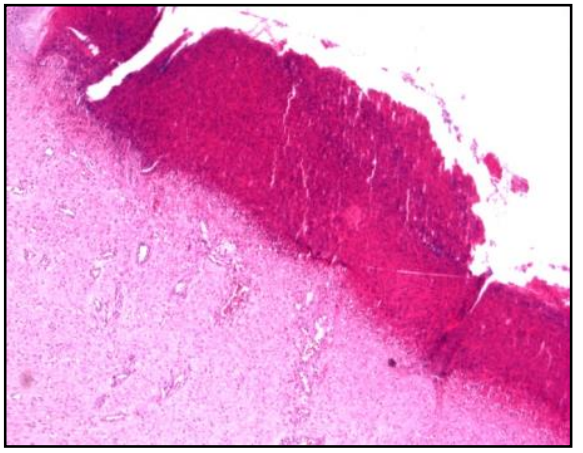

Figure 8: Pododernatitis (multiplication $\mathrm{x} 40$ )

Source: Histology Laboratory, Faculty of Veterinary of Complutense University of Madrid.

Also as a score 4 , we have in figures 9 and 10 , a purulent dermatitis or suppurative heterophile abundant, resulting from a secondary bacterial infection, that even developing a fibroplasia, with the presence of angioblastos and fibroblasts, begin to form connective tissue (granulation tissue). 


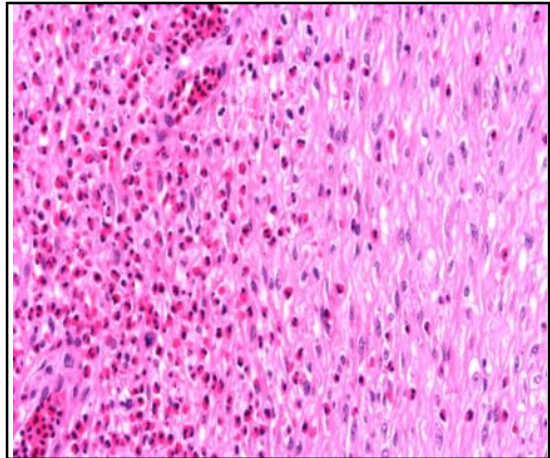

Figure 9: Pododernatitis (multiplication x200)

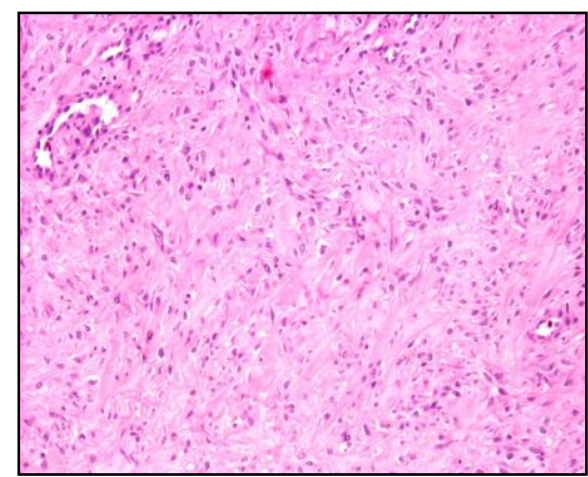

Figure 10: Pododernatitis (multiplication $\mathrm{x} 40$ )

Source: Histology Laboratory, Faculty of Veterinary of Complutense University of Madrid.

Our overall objective in this study

was to evaluate and observe the differences in injury or not of pododermatitis among broilers raised in different climates, hot in Brazil and cold in Spain, with different densities of birds per square meter and reuse or not of the litter.

In the specific objectives, we made comparisons of injuries or not of pododermatitis between broilers, according to sex, age and the side on which bird developed in the aviary, in each country.

\section{Material and Methods}

The whole methodology used in Brazil, has been applied in Spain following the manner described below.

The first data collection period was held in Brazil during the warmer months of April and May, in 2015, in four negative pressures poultry with controlled temperature of Pacatuba Hortigranjeira company, in the geographical environment of the semi-arid zone around the town of Aracoiaba, about $100 \mathrm{~km}$ from Fortaleza, near the central hinterland of the state of Ceará, with the geographic location of $40^{\circ} 21 ' 20$ "south latitude, $38^{\circ} 49^{\prime} 40^{\prime \prime}$ west longitude, $101 \mathrm{~m}$ high above sea level (ARACOIABA, 2014) and relative humidity of $50 \%$ with an average minimum temperature of $28^{\circ} \mathrm{C}$ and maximum $36^{\circ} \mathrm{C}$, according to technical information of the company.

For the second period, the data collection was carried out in Spain during the coldest months of February and March in 2016, in four negative pressures poultry with controlled temperature of a NUTRAVE company in region of Castilla La Mancha, next city of Madrid, the capital state of Madrid, with geographical location $40^{\circ}$ 24 '59 "north latitude and 03 ० 42'09" west longitude (CARTA-NATAL, 2014), with $655 \mathrm{~m}$ high above sea level (MADRID, 2014 ), the average relative humidity of $70 \%$ (METEOCLIMATIC, 2014) with a 
minimum temperature of $2^{\circ} \mathrm{C}$ and a maximum of $12^{\circ} \mathrm{C}$ (ACCUWEATHER, 2014).

Were used 144 broilers from each country in a completely randomized design, in two temperatures (a farm in the hot region of Brazil and a farm in the cold region in Spain), three different ages (14, 28 and 42 days), and sex and sides effects (coolers and exhausters), with four replications (aviary), each repetition with 36 broilers, 18 males and 18 females, resulting in a factorial $2 \times 3$ $\mathrm{x} 2 \times 2$.

The temperature external collections were performed by digital laser apparatus in the extreme corners of roofs always in the same location and schedule, next to the coolers (cooling) and exhausters respectively. Internally, both air relative

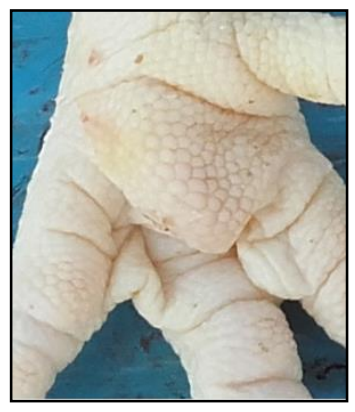

Figure 11: Score 1

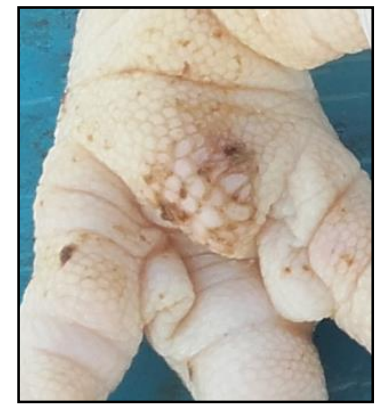

Figure 12: Score 2

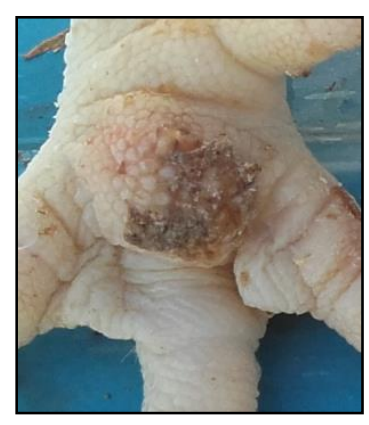

Figure 13: Score 3

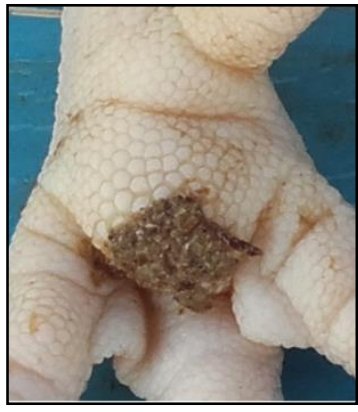

Figure 14: Score 4

Source: Pictures obtained during the research. 
Later the organization of data, each country teams made respectively review, through the display of images.

Data analysis was performed using the Statistical Analysis Systems (SAS Institute, 1990).

Analyses of variance were performed with the GLM procedure. For the media, when there was significance at $\mathrm{P}<0.05$, we used the DUNCAN test (RUIZ-MAYA, 1986).

\section{Results and Discussion}

According to the season in each country, the temperatures were different, being in Brazil always higher (Table 1), independent of the ages of the birds and the aviary area, however with a little variation (Graphic 1).

Table 1. Temperatures $\left({ }^{\circ} \mathrm{C}\right)$ average $(\mathrm{X})$ obtained in Brazil as the ages of the birds and the area of the aviary.

\begin{tabular}{lcccc}
\hline \multicolumn{1}{c}{ BRAZIL Temperature } & $\mathbf{1 4}$ days & $\mathbf{2 8}$ days & $\mathbf{4 2}$ days & $\overline{\mathrm{X}}$ \\
\hline Exhausters external & 35,35 & 36,23 & 36,18 & 35,92 \\
Coolers external & 35,45 & 35,45 & 35,68 & 35,53 \\
Exhausters internal & 29,85 & 31,13 & 31,48 & 30,82 \\
Coolers internal & 28,70 & 29,35 & 32,75 & 30,27 \\
General & 32,34 & 33,04 & 34,02 & 33,13 \\
\hline
\end{tabular}

Graphic 1. Temperatures $\left({ }^{\circ} \mathrm{C}\right)$ average obtained in Brazil as the ages of the poultry and the area of the aviaries.

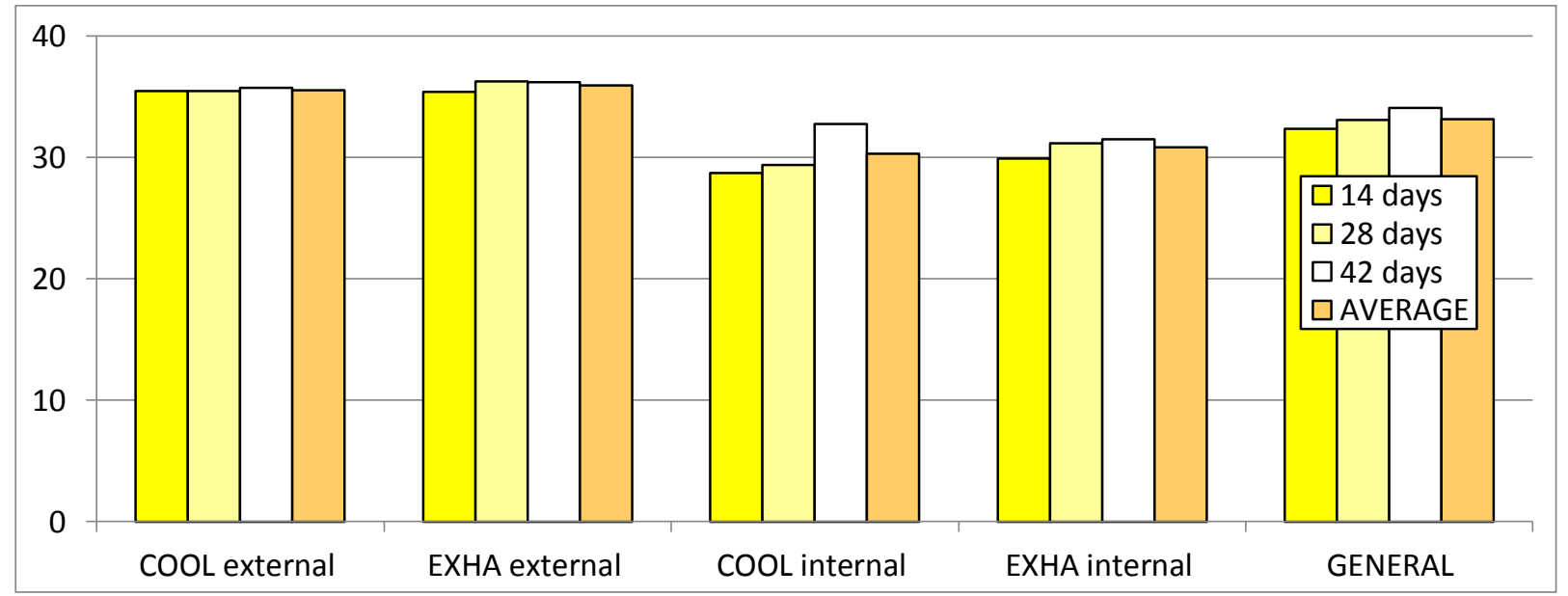

Cool $=$ Coolers $;$ Exha $=$ Exhausters.

In Spain, the average temperatures were much lower (Table 2) than the obtained in Brazil, mainly internally as the area in aviaries and ages of the poultry (Graphic 2). 
Benevides et al., Revista Brasileira de Higiene e Sanidade Animal (v.10, n.3) p. 330 - 350, jul - set (2016)

Table 2. Temperatures $\left({ }^{\circ} \mathrm{C}\right)$ average $(\mathrm{X})$ obtained in Spain as the ages of the poultry and the area of the aviaries.

\begin{tabular}{lcccc}
\hline \multicolumn{1}{c}{ SPAIN Temperature } & $\mathbf{1 4}$ days & $\mathbf{2 8}$ days & $\mathbf{4 2}$ days & $\overline{\mathrm{X}}$ \\
\hline Exhausters external & 8,63 & 18,43 & 13,78 & 13,61 \\
Coolers external & 9,98 & 13,08 & 12,33 & 11,79 \\
Exhausters internal & 28,93 & 23,60 & 20,55 & 24,36 \\
Coolers internal & 28,10 & 23,58 & 20,20 & 23,96 \\
General & 18,91 & 19,67 & 16,71 & 18,43 \\
\hline
\end{tabular}

Graphic 2. Temperatures $\left({ }^{\circ} \mathrm{C}\right)$ average obtained in Spain as the ages of the poultry and the area of the aviaries.

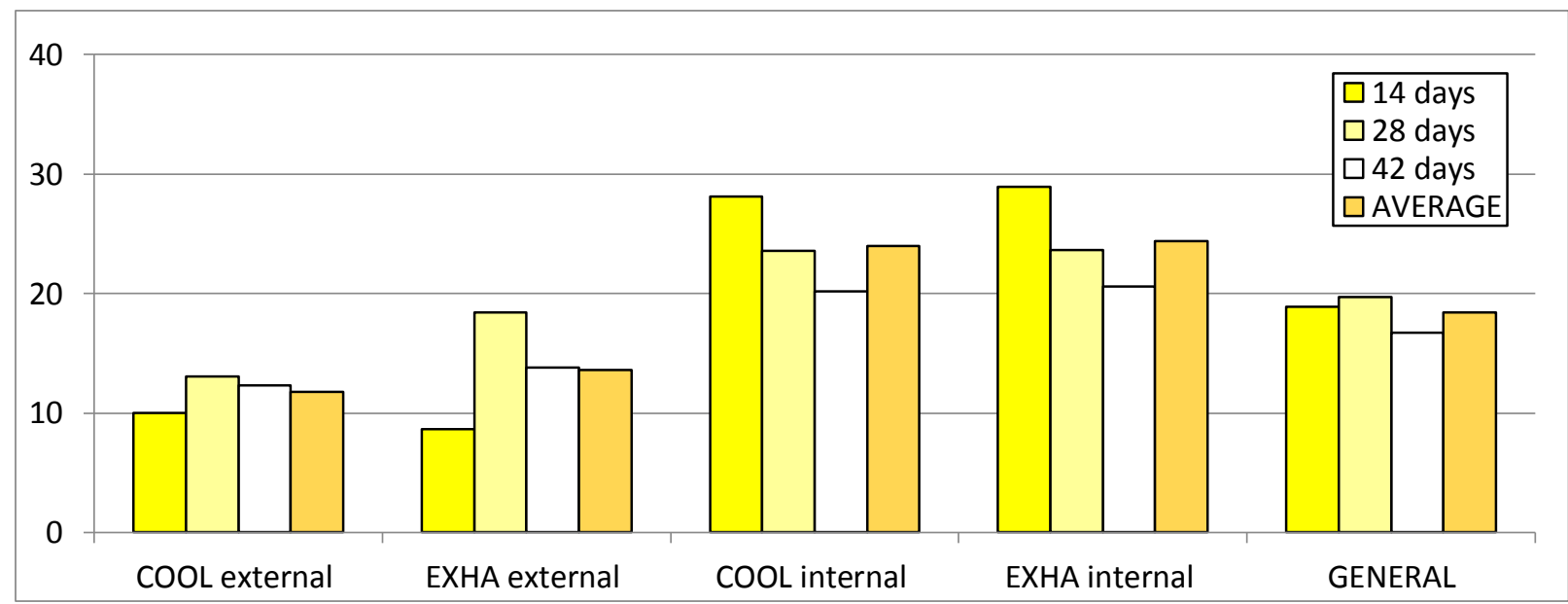

Cool $=$ Coolers; Exha $=$ Exhausters.

The relative humidity was higher in Brazil in media and in any area of aviaries (Table 3), expected feature in hot climate regions (Graphic 3).

Table 3. Relative humidity of air (\%) average (X) obtained by side of the aviaries in both countries.

\begin{tabular}{lccc}
\hline \multicolumn{1}{c}{ Relative humidity of air } & internal Exhausters & internal Coolers & $\overline{\mathrm{X}}$ \\
\hline BRAZIL & 71,09 & 72,93 & 72,01 \\
SPAIN & 60,33 & 61,33 & 60,83 \\
\hline
\end{tabular}


Benevides et al., Revista Brasileira de Higiene e Sanidade Animal (v.10, n.3) p. 330 - 350, jul - set (2016)

Graphic 3. Relative humidity air (\%) average obtained by side aviaries in both countries.

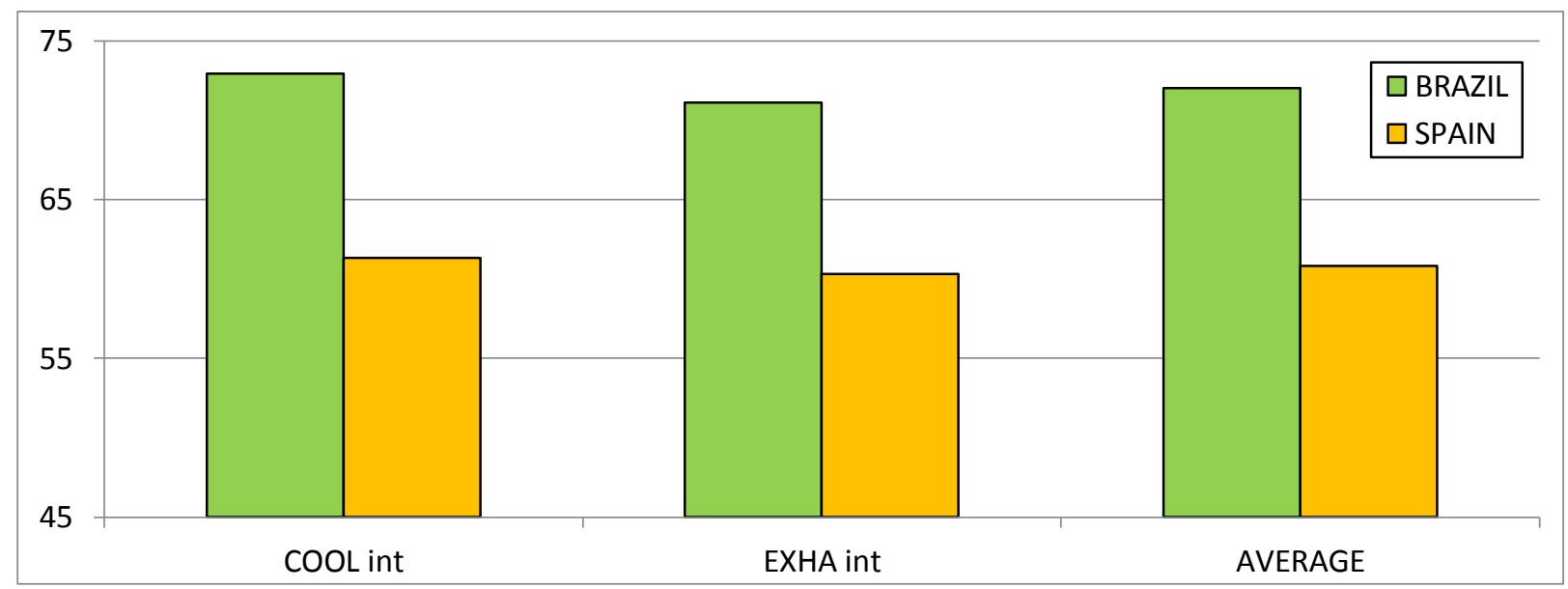

Cool $=$ Coolers $;$ Exha $=$ Exhausters .

The averages of live weight, in both the countries there were NS (not grams, by age and sex, showed the following significant difference) with $\mathrm{P}<0.05$. values in table 4 and graphic 4 , in which

Table 4. Live weight (grams) average (X), by age and gender in Brazil and Spain.

\begin{tabular}{lccccccccc}
\hline & \multicolumn{7}{c}{ BRAZIL } & \multicolumn{1}{c}{ SPAIN } \\
\hline \multicolumn{1}{c}{ SEX } & 14 days & 28 days & 42 days & $\bar{X}$ & 14 days & 28 days & 42 days & $\bar{X}$ & N \\
\hline Male & 502,08 & 1572,92 & 2789,58 & 1620,10 & 505,67 & 1455,83 & 2838,33 & 1599,90 & 144 \\
Female & 504,17 & 1437,50 & 2468,75 & 1466,00 & 440,88 & 1258,33 & 2435,83 & 1378,30 & 144 \\
\hline
\end{tabular}

$\mathrm{N}=$ number of observation.

Graphic 4. Live weight (grams) average per sex in Brazil and Spain.

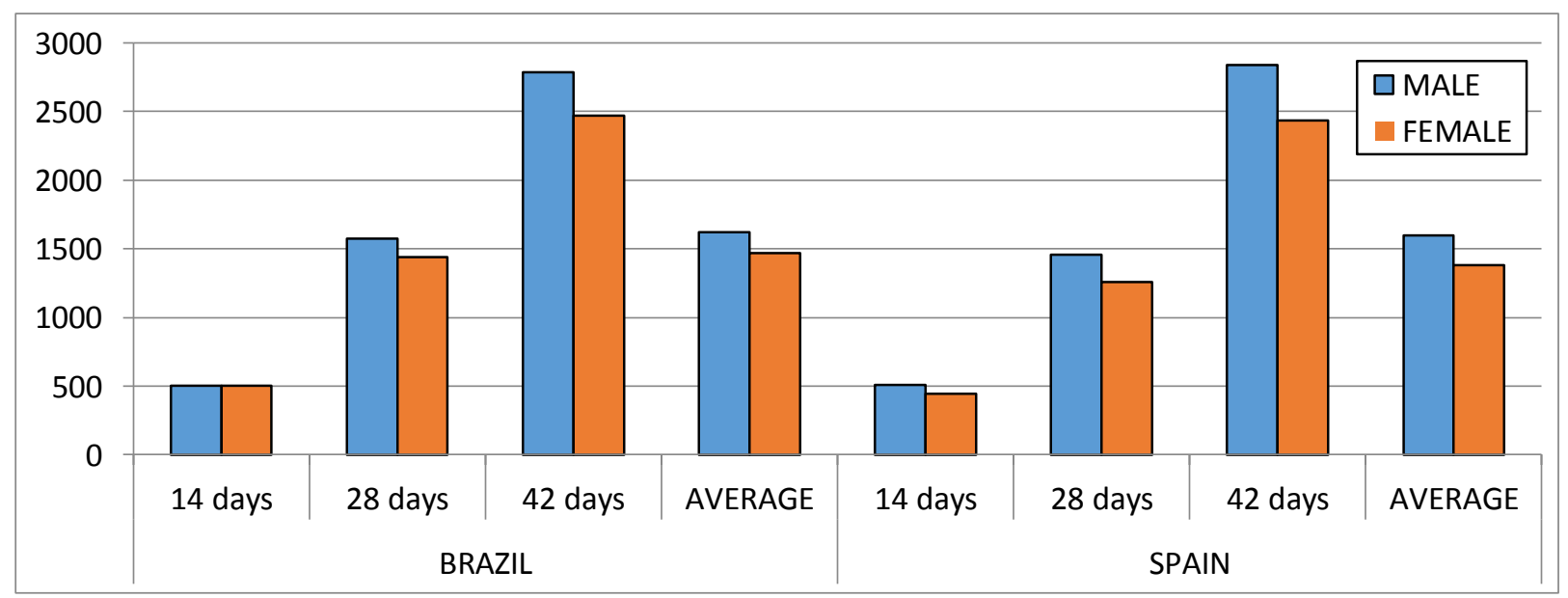


Benevides et al., Revista Brasileira de Higiene e Sanidade Animal (v.10, n.3) p. 330 - 350, jul - set (2016)

The averages body weight in grams by age and side of the aviaries, showed the following values in Table 5 and graphic 5 , in which both the countries also there were NS with $\mathrm{P}<0.05$.

Table 5. Live weight (grams) average $(\mathrm{X})$, by age and side of the chicken farms in Brazil and Spain.

\begin{tabular}{|c|c|c|c|c|c|c|c|c|c|}
\hline \multirow[b]{2}{*}{ Side } & \multirow{3}{*}{$\begin{array}{c}14 \\
\text { days }\end{array}$} & \multicolumn{3}{|c|}{ BRAZIL } & \multicolumn{2}{|c|}{ SPAIN } & \multirow{3}{*}{$\begin{array}{c}42 \\
\text { days }\end{array}$} & \multirow{3}{*}{$\overline{\mathrm{X}}$} & \multirow{3}{*}{$\mathbf{N}$} \\
\hline & & 28 & 42 & $\overline{\mathrm{X}}$ & 14 & 28 & & & \\
\hline & & days & days & & days & days & & & \\
\hline \multirow[t]{2}{*}{ Cooler } & & 1550,0 & 2643,7 & 1566,7 & & 1349,5 & 2563,3 & 1467,2 & 144 \\
\hline & 475,00 & 0 & 5 & 0 & 488,63 & 8 & 3 & 0 & \\
\hline \multirow[t]{2}{*}{ Exhauster } & & 1460,4 & 2614,5 & 1519,4 & & 1364,5 & 2710,8 & 1511,1 & 144 \\
\hline & 481,25 & 2 & 8 & 0 & 457,92 & 8 & 3 & 0 & \\
\hline
\end{tabular}

$\mathrm{N}=$ number of observation.

Graphic 5. Live weight (grams) average, by age and side of the chicken farms in Brazil and Spain.

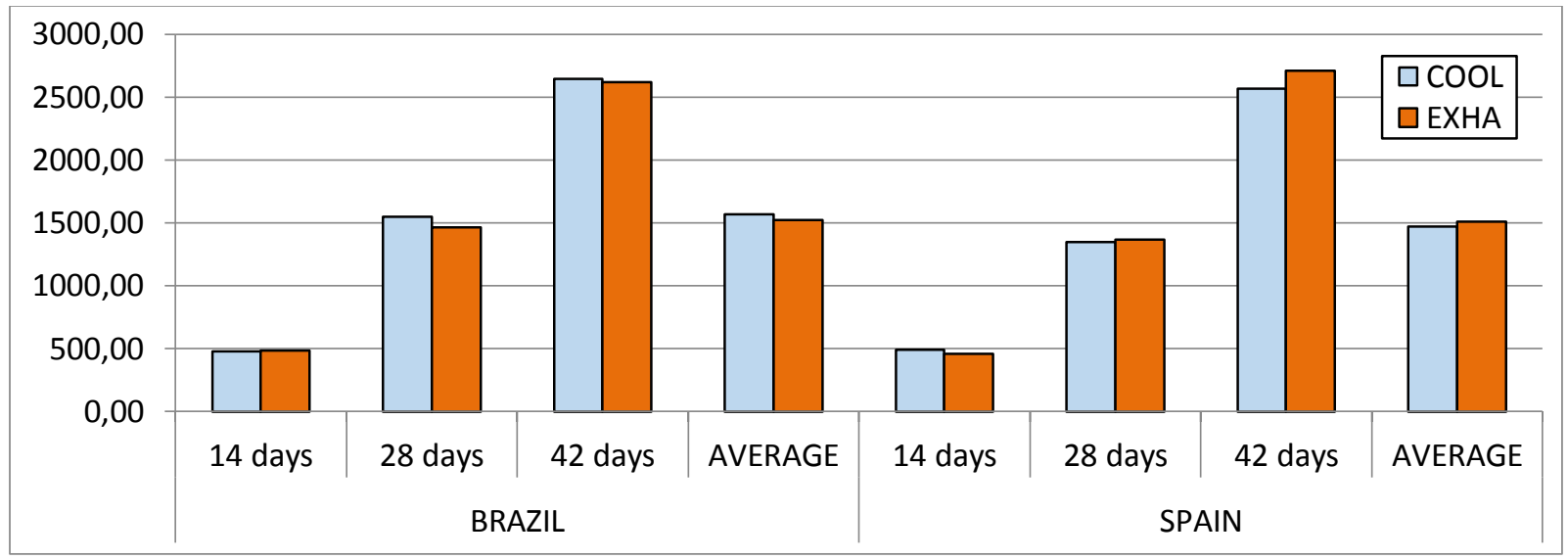

Cool $=$ Coolers $;$ Exha $=$ Exhausters .

The averages scores of lesions of To the litter of aviaries, were used pododermatitis by aviary, not show significant differences (Table 6) in Brazil, despite the higher values than those of Spain, which had significant differences $(\mathrm{P}<0.05)$. 
Benevides et al., Revista Brasileira de Higiene e Sanidade Animal (v.10, n.3) p. 330 - 350, jul - set (2016)

Table 6. Pododermatitis Scores by aviary and by parents.

\begin{tabular}{cccc}
\hline Aviary & BRAZIL & SPAIN & N \\
\hline A & $2,7431^{\mathrm{a}}$ & $2,2222^{\mathrm{a}}$ & 72 \\
$\mathbf{B}$ & $2,9236^{\mathrm{a}}$ & $1,5278^{\mathrm{b}}$ & 72 \\
$\mathbf{C}$ & $2,6042^{\mathrm{a}}$ & $1,6111^{\mathrm{b}}$ & 72 \\
$\mathbf{D}$ & $2,9514^{\mathrm{a}}$ & $1,3056^{\mathrm{b}}$ & 72
\end{tabular}

${ }^{\mathrm{ab}}$ Distinct index on the same column indicates significant difference $(\mathrm{P}<0,05)$ between the average.

$\mathrm{N}=$ number of observation.

Only the aviary A, in Spain, daily management by a worker, only obtained a higher score (Graphic 6), possibly computerized monitoring. caused by management, since it had not

Graphic 6. Pododermatitis Scores by aviary by country.

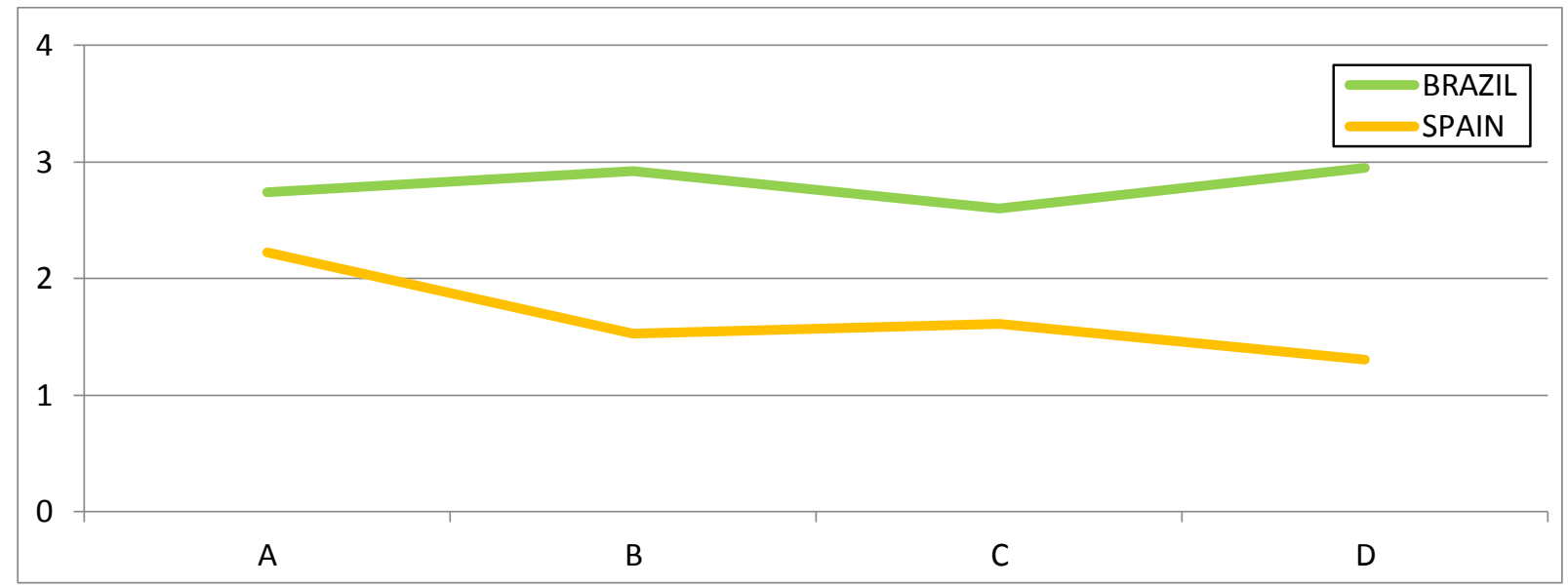

The scores of lesions of

pododermatitis by age showed significant differences $(\mathrm{P}<0.05)$ in both countries

(Table 7), 14 days in relation to other age groups, noting that Brazil values were higher than the average of Spain (Graphic 7).

Table 7. Pododermatitis Scores by age by country.

\begin{tabular}{cccc}
\hline Age & BRAZIL & SPAIN & N \\
\hline 14 days & $2,4167^{\mathrm{b}}$ & $1,1042^{\mathrm{b}}$ & 96 \\
$\mathbf{2 8}$ days & $3,0313^{\mathrm{a}}$ & $2,0000^{\mathrm{a}}$ & 96 \\
$\mathbf{4 2}$ days & $2,9688^{\mathrm{a}}$ & $1,8958^{\mathrm{a}}$ & 96 \\
\hline
\end{tabular}

${ }^{a}$ Distinct índex on the same column indicates significant difference $(\mathrm{P}<0,05)$ between the average.

$\mathrm{N}=$ number of observations. 
Graphic 7. Pododermatitis Score by age by country.

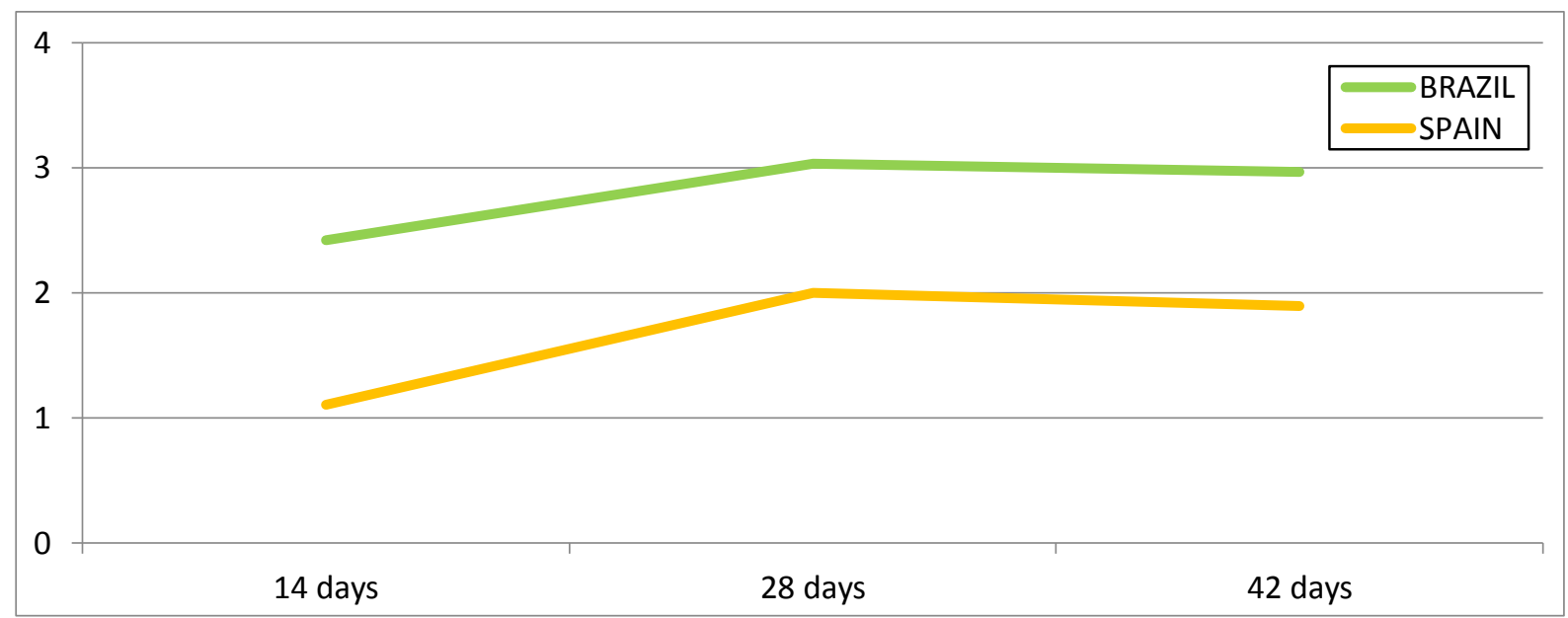

Regarding the ages with 28 and 42

Males and females showed no days, the lesions were significantly higher significant differences in any country (Table than 14 days in both countries, 8), although the averages in Brazil were demonstrating an advance in pododermatitis higher for both sexes (Graphic 8). lesions after this age.

Table 8. Pododermatitis Score by sex by country.

\begin{tabular}{cccc}
\hline Sex & BRAZIL & SPAIN & N \\
\hline Male & 2,8819 & 1,6250 & 144 \\
Female & 2,7292 & 1,7083 & 144
\end{tabular}

Pododermatitis Score average by sex on average significant for Brazil and no significant for Spain $(\mathrm{P}<0,05)$.

$\mathrm{N}=$ number of observation.

Graphic 8. Pododermatitis Score by sex by country.

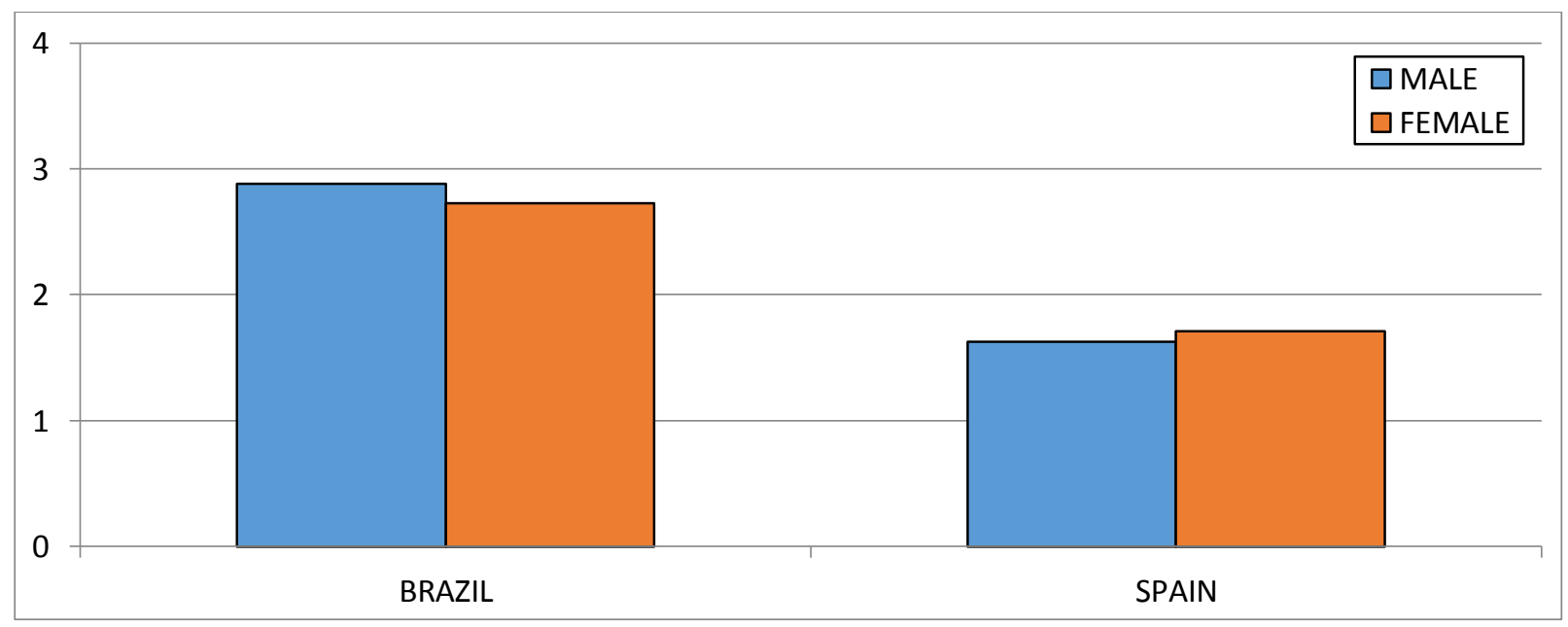


Benevides et al., Revista Brasileira de Higiene e Sanidade Animal (v.10, n.3) p. 330 - 350, jul - set (2016)

The index scores of lesions of pododermatitis by aviary side showed significant differences $(\mathrm{P}<0.05)$ only to
Brazil (Table 9), noting that these values were on average higher than in Spain (Graphic 9).

Table 9. Pododermatitis Score by side by country.

\begin{tabular}{cccc}
\hline Side & BRAZIL & SPAIN & N \\
\hline Coolers & 3,1181 & 1,6528 & 144 \\
\hline Exhausters & 2,4931 & 1,6806 & 144
\end{tabular}

Pododermatitis Score average by on average significant for Brazil and no significant for Spain $(\mathrm{P}<0,05)$. $\mathrm{N}=$ number of observation.

Graphic 9. Pododermatitis Score by sex by country.

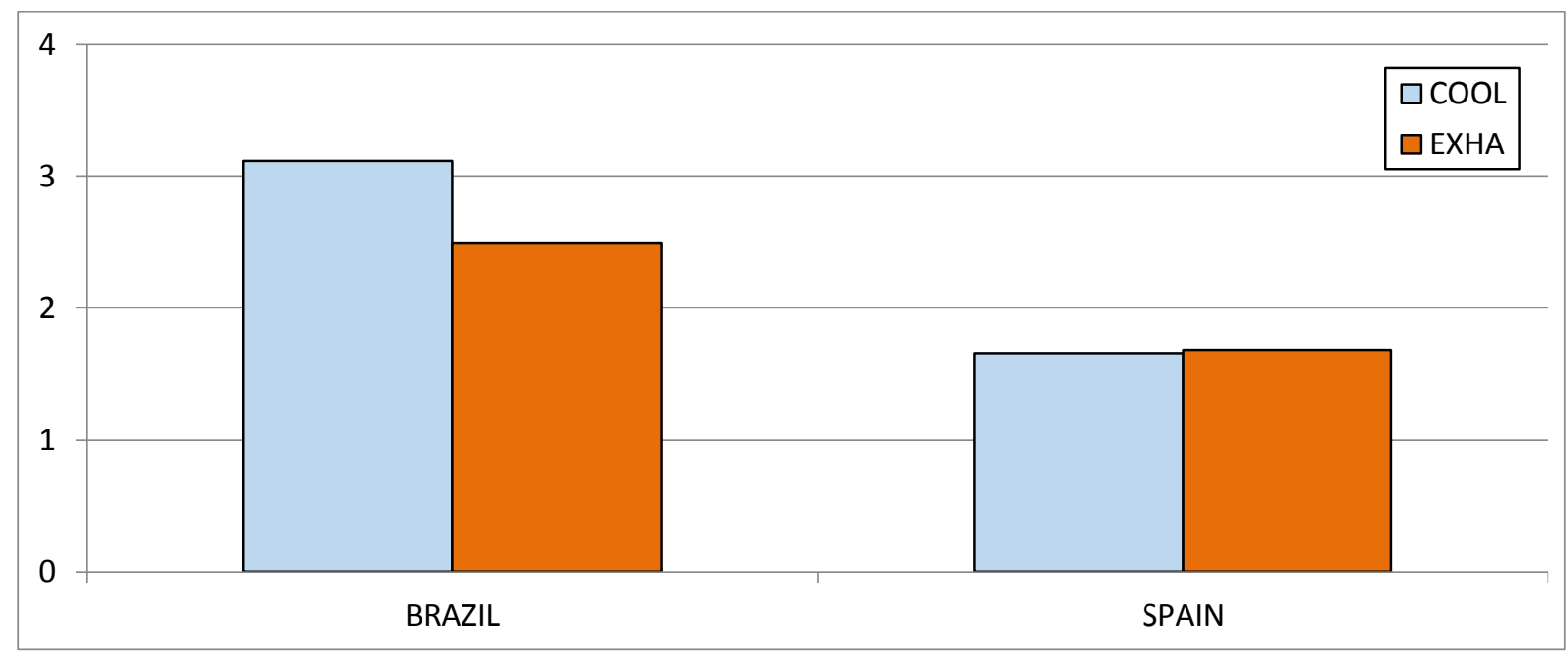

Cool $=$ Coolers $;$ Exha $=$ Exhausters .

The live weight of broilers in as the interaction of these parameters. But, Brazil (Table 10 e 11), demonstrated had no interaction to pad dermatitis, in spite statistical values highly significant $(\mathrm{P}<0,001)$, according to age and sex, as well of high significance $(\mathrm{P}<0,001)$ for age and part of the aviary in isolation. 
Benevides et al., Revista Brasileira de Higiene e Sanidade Animal (v.10, n.3) p. 330 - 350, jul - set (2016)

Table 10. Relationship of age, gender and side with foot pad dermatitis in Brazil.

\begin{tabular}{|c|c|c|c|c|}
\hline Age & Gender & Side & Live weight & Foot pad \\
\hline 14 & $\mathrm{~F}$ & $E$ & 467 & 2 \\
\hline 14 & $\mathrm{~F}$ & $\mathrm{C}$ & 517 & 2 \\
\hline 14 & M & $\mathrm{E}$ & 500 & 2 \\
\hline 14 & M & $\mathrm{C}$ & 496 & 2 \\
\hline 28 & $\mathrm{~F}$ & $\mathrm{E}$ & 1433 & 3 \\
\hline 28 & $\mathrm{~F}$ & $\mathrm{C}$ & 1442 & 3 \\
\hline 28 & M & $\mathrm{E}$ & 1488 & 3 \\
\hline 28 & M & $\mathrm{C}$ & 1658 & 3 \\
\hline 42 & $\mathrm{~F}$ & $\mathrm{E}$ & 2504 & 3 \\
\hline 42 & $\mathrm{~F}$ & $\mathrm{C}$ & 2433 & 3 \\
\hline 42 & M & $\mathrm{E}$ & 2725 & 3 \\
\hline 42 & M & $\mathrm{C}$ & 2854 & 3 \\
\hline \multicolumn{5}{|c|}{ Main Effects } \\
\hline \multirow[t]{3}{*}{ Age } & 14 & & $495^{\mathrm{a}}$ & $2^{a}$ \\
\hline & 28 & & $1505^{\mathrm{b}}$ & $3^{b}$ \\
\hline & 42 & & $2629^{c}$ & $3^{\mathrm{b}}$ \\
\hline \multirow[t]{2}{*}{ Sex } & $\mathrm{F}$ & & 1466 & 3 \\
\hline & M & & 1620 & 3 \\
\hline \multirow[t]{2}{*}{ Side } & $\mathrm{E}$ & & 1520 & 3 \\
\hline & $\mathrm{C}$ & & 1567 & 3 \\
\hline Sem & & & 57.3 & 0.26 \\
\hline \multirow[t]{7}{*}{ P- valor } & AGE & & $<0.001$ & $<0.001$ \\
\hline & GEN & & $<0.001$ & 0.19 \\
\hline & SIDE & & 0.15 & $<0.001$ \\
\hline & AGE*GEN & & $<0.001$ & 0.41 \\
\hline & AGE*SIDE & & 0.65 & 0.44 \\
\hline & GEN*SIDE & & 0.12 & 0.85 \\
\hline & $\mathrm{AGE}^{*} \mathrm{GEN} * \mathrm{SIDE}$ & & 0.23 & 0.41 \\
\hline
\end{tabular}


Benevides et al., Revista Brasileira de Higiene e Sanidade Animal (v.10, n.3) p. 330 - 350, jul - set (2016)

Table 11. Relationship of age, gender and side with foot pad dermatitis in Spain.

\begin{tabular}{|c|c|c|c|c|}
\hline Age & Gender & Side & Live weight & Foot pad \\
\hline 14 & $\mathrm{~F}$ & $E$ & 430 & 1 \\
\hline 14 & $\mathrm{~F}$ & $\mathrm{C}$ & 452 & 1 \\
\hline 14 & M & $\mathrm{E}$ & 486 & 1 \\
\hline 14 & M & $\mathrm{C}$ & 525 & 1 \\
\hline 28 & $\mathrm{~F}$ & $\mathrm{E}$ & 1248 & 2 \\
\hline 28 & F & $\mathrm{C}$ & 1269 & 2 \\
\hline 28 & M & $\mathrm{E}$ & 1482 & 2 \\
\hline 28 & M & $\mathrm{C}$ & 1430 & 2 \\
\hline 42 & $\mathrm{~F}$ & $\mathrm{E}$ & 2583 & 2 \\
\hline 42 & $\mathrm{~F}$ & $\mathrm{C}$ & 2288 & 2 \\
\hline 42 & M & $\mathrm{E}$ & 2838 & 2 \\
\hline 42 & M & $\mathrm{C}$ & 2838 & 2 \\
\hline \multicolumn{5}{|c|}{ Main Effects } \\
\hline \multirow[t]{3}{*}{ Age } & 14 & & $473^{\mathrm{a}}$ & $1^{\mathrm{a}}$ \\
\hline & 28 & & $1357^{b}$ & $2^{b}$ \\
\hline & 42 & & $2637^{c}$ & $2^{\mathrm{b}}$ \\
\hline \multirow[t]{2}{*}{ Sex } & $\mathrm{F}$ & & 1378 & 2 \\
\hline & M & & 1560 & 2 \\
\hline \multirow[t]{2}{*}{ Side } & $\mathrm{E}$ & & 1511 & 2 \\
\hline & $\mathrm{C}$ & & 1467 & 2 \\
\hline Sem & & & 62.3 & 0.23 \\
\hline \multirow[t]{7}{*}{ P- valor } & AGE & & $<0.001$ & $<0.001$ \\
\hline & GEN & & $<0.001$ & 0.53 \\
\hline & SIDE & & 0.22 & 0.83 \\
\hline & $\mathrm{AGE} * \mathrm{GEN}$ & & $<0.001$ & 0.79 \\
\hline & AGE*SIDE & & 0.11 & 0.87 \\
\hline & GEN*SIDE & & 0.27 & 1.00 \\
\hline & $\mathrm{AGE} * \mathrm{GEN} * \mathrm{SIDE}$ & & 0.11 & 0.29 \\
\hline
\end{tabular}




\section{Conclusions}

We can conclude that in the conditions that the research was conducted, the pododermatitis in broilers may be different for a few reasons. The area of coolers, for being wetter, indicates that it may increase the injury index, with the aggravation of the highest external temperature and the highest relative humidity of the air, as is the case in Brazil.

The age of birds is also a factor that can cause the pododermatitis due to progressive weight gain. Depending on the situation that the litter is, either softer or more rigid, you can also change the pododermatitis score. We conclude, mainly, that the external ambience influences the internal ambience and, added to handling and recycling litter, may interferes in the increase of pododermatitis index with the age of the birds and to the extent that they gain more weight.

The area of coolers, for being wetter, indicates that it may increase the injury index, with the aggravation of the highest external

\section{References}

1. ABPA - Associação Brasileira de Proteína Animal. Disponível br.com.br/setores/avicultura/mercadomundial/frango> Acesso em: 16 maio 2016.

2. ACCUWEATHER. Disponível em <http://www.accuweather.com> Acesso em: 26 jun. 2014. temperature and the highest relative humidity of the air, as is the case in Brazil. The age of birds is also a factor that can cause the pododermatitis due to progressive weight gain. Depending on the situation that the litter is, either softer or more rigid, you can also change the pododermatitis score.

\section{Thanks}

To the Laboratory of Veterinary Parasitology and the Faculty of Veterinary Medicine of the UECE, by the logistical support on the part of the research carried out in Brazil. The Laboratory of Autopsies of the Department of Medicine and Surgery of the Faculty of Veterinary Medicine of the UCM, the logistical support on the part of research conducted in Spain. The Department of Statistics of UCM, for processing and statistical analysis of data obtained from all parts of the survey. Companies PACATUBA HORTIGRANJEIRA, Brazil and NUTRAVE, Spain, for gave us their spaces and technical staff for the implementation of this scientific research.

3. ARACOIABA. Disponível
<http://www.aracoiaba.ce.gov.br> Acesso em: 26
jun. 2014.

4. ASK, B. Genetic variation of contact dermatitis in broilers. Poultry Science, 89: 866-875, 2010. 
5. BASSLER, W.; ARNOULD, C., BUTTERWORTH, A.; COLIN, L.; JONG, I. DE, FERRANTE, V., BLOKHUIS, H. Potential risk factors associated with contact dermatitis, lameness , negative emotional state, and fear of humans in broiler chicken flocks. Poultry Science, 92: 28112826, 2013.

6. BENEVIDES, W.S.; BEZERRA NETO, O.F.; CUSTÓDIO, J. Questionamento do BEA - Bem Estar Animal e Produtividade de frangos de corte criados em diferentes tipos de instalações. In: AVESUI 2013, Florianópolis, Resumos... Florianópolis: GESSULI, 2013a.

7. BENEVIDES, W.S.; BEZERRA NETO, O.F.; CUSTÓDIO, J. Questionamento do BEA e produtividade de galinhas poedeiras criadas em diferentes tipos de Instalações. Avicultura Industrial, Itu, n. 1, p. 52-55, $2013 \mathrm{~b}$.

8. BERCHIERI JR. Â.; SILVA, E.N.; DI FÁBIO, J.;SESTI, L.; ZUANAZE, M.A.F. Doenças das Aves. $2^{a}$ Edição. Campinas: FACTA. 2009. 1104p.

9. BERNARDI, R. Problemas locomotores em frango de corte, UFGD, Dourados - MS, 2011. 61 p. (Dissertação de Mestrado) - Universidade Federal da Grande Dourados, MS, 2011.

10. CARTA-NATAL. Disponível em <http://www.carta-natal.es> Acesso em: 26 jun. 2014.

11. CHEN, J.; TELLEZ, G.; AND ESCOBAR, J. Identification of Biomarkers for Footpad Dermatitis Development and Wound Healin, USA 6, 26, 2016.

12. DUNLOP, M.; MOSS, A.; GROVES, P.; WILKINSON, S.; STUETZ, R.; SELLE, P.H. The multidimensional causal factors of "wet litter" in chicken-meat production. Science of The Total Environment, 766-776, 2016.

13. FAROUK, M.; PUFPAFF, K.M.; AMIR, M. Industrial halal meat production and animal welfare: A review. Meat Science, Pag 2-3, 2016.

14. GOCSIK, É.; BROOSHOOFT, S.D.; JONG DE, I.C.; SAATKAMP, H. Cost-efficiency of animal welfare in broiler production systems : A pilot study using the Welfare Quality assessment protocol. Agsy, 146: 55-69, 2016.
15. HASHIMOTO, S.; YAMAZAKI, K.;OBI, T.; TAKASE, K. Footpad dermatitis in broiler chickens in Japan. The Journal of Veterinary Medical Science / the Japanese Society of Veterinary Science, 73: 293-297, 2011.

16. MADRID. Disponível em <http://www.madrid.es> Acesso em: 26 jun. 2014.

17. MARTRENCHAR, A.; BOILLETOT, E.; HUONNIC, D.; POL, F. Risk factors for foot-pad dermatitis in chicken and turkey broilers in France. Preventive Veterinary Medicine, 52: 213-226, 2002.

18. MELLO, J.L.M.; BORBA, H.; GIAMPIETROGANECO, A.; VIEIRA, L.D. C.; BOIAGO, M.M.; SOUZA, P.A.; MARTINS, M. R. F. B. Incidência de pododermatite de contato em frangos de corte submetidos a estresse térmico. In:XXII LATIN AMERICAN POULTRY CONGRESS, 2011. Buenos Aires, Argentina. Anais... Buenos Aires, Argentina: 2011.

19. MENDES, A.A.; NAAS, I.A.; MACARI, M. Produção de Frangos de Corte. Campinas: FACTA. 2004. 365p.

20. METEOCLIMATIC. Disponível em <http://www.meteoclimatic.net >Acesso em: 26 jun. 2014.

21. RUIZ-MAYA, L. Métodos estadísticos de investigación. Instituto Nacional de Estadística. Madrid, (1986).

22. SANTOS, R.L.; NUNES, V.A.; BAIÃO, N.C. Pododermatite de contato em frangos de corte. Arquivo Brasileiro de Medicina Veterinaria e Zootecnia, Belo Horizonte, v.54, n.6, 2002.

23. SARAIVA, S.; SARAIVA, C.; STILWELL, G. Feather conditions and clinical scores as indicators of broilers welfare at the slaughterhouse. Research in Veterinary Science. Volumen: 43-50, 2016.

24. SAS Institute SAS User's Guide. Versión 6, SAS Institute, Cary, N.C. Sci. 46:1447-1469. (1990).

25. SHEPHERD, E.M.; FAIRCHILD, B.D. Footpad dermatitis in poultry. Poultry Science, 89: 20432051, 2010. 
Benevides et al., Revista Brasileira de Higiene e Sanidade Animal (v.10, n.3) p. 330 - 350, jul - set (2016)

26. SINCLAIR, A.; WEBER WYNEKEN, C.; VELDKAMP, T.; VINCO, L.J.; HOCKING, P. M. Behavioural assessment of pain in commercial turkeys (Meleagris gallopavo) with foot pad dermatitis. British Poultry Science, Volumen: pag $1668,2015$.

27.TEIXEIRA, A.; OLIVEIRA, M.; MENEZES, J.; GOUVEA, B.; TEIXEIRA, S.; GOMES, A. Poultry litter of wood shavings and/or sugarcane bagasse: animal performance and bed quality. Revista Colombiana de Ciencias Pecuarias, 28: 55-64, 2015.

28. WEBER WYNEKEN, C.; SINCLAIR, A.; VELDKAMP, T.; VINCO, L.J.; HOCKING, P. M. Footpad dermatitis and pain assessment in turkey poults using analgesia and objective gait analysis. British Poultry Science, 1668: 1-9, 2015.

29. ZHANG, H.; JIAO, H.; CHAO, SONG, Z.; LIN, H. Effect of Alum-Amended Litter and Stocking Density on Ammonia Release and Footpad and Hock Dermatitis of Broilers. Agricultural Sciences in China, 10: 777-785, 2011. 
Benevides et al., Revista Brasileira de Higiene e Sanidade Animal (v.10, n.3) p. 330 - 350, jul - set (2016) 